\begin{tabular}{lc}
\hline \multicolumn{1}{c}{ A N N A L E S } \\
UNIVERSitatis MARIAE CURIE-SKŁODOWSKA \\
LUBLIN - POLONIA \\
SOL.XXIV,2 \\
SECTIOK
\end{tabular}

Instytut Studiów Międzynarodowych Uniwersytetu Wrocławskiego

\author{
ANNA UMIŃSKA-WORONIECKA
}

\title{
Kategoria przywództwa politycznego w analizie polityki zagranicznej
}

The Concept of Leadership in Foreign Policy Analysis

\begin{abstract}
ABSTRAKT
Analiza polityki zagranicznej ujmowana jako subdyscyplina stosunków międzynarodowych albo alternatywnie wyodrębniony obszar badawczy koncentruje się na wyjaśnianiu polityki zagranicznej, nawiązując do teoretycznych założeń i twierdzeń na temat ludzkich zachowań jednostek. Eksplikacja zachowań i decyzji decydentów podejmowanych w ramach polityki zagranicznej może wymagać sięgnięcia do kategorii i narzędzi wypracowanych w ramach innych dyscyplin. Celem artykułu jest wskazanie interdyscyplinarności badań, zwłaszcza przy przyjętej przez autorkę perspektywie jednostkowego poziomu analizy polityki zagranicznej. Zastosowanie narzędzi i kategorii właściwych studiom nad przywództwem politycznym, a także psychologii politycznej może umożliwić większą niż dotychczas weryfikowalność twierdzeń w badaniach nad polityką zagraniczną.
\end{abstract}

Słowa kluczowe: analiza polityki zagranicznej, jednostka, teoria kodu operacyjnego, przywództwo polityczne, podejście poznawcze

\section{WSTĘP}

Czy jednostka ma znaczenie w polityce światowej? [Hudson 2014: 39] Od tak postawionego pytania Valerie Hudson zaczęła rozdział poświęcony poziomowi jednostki w analizie polityki zagranicznej. Zdaniem autorki, przy uwzględnieniu poszczególnych paradygmatów stosunków międzynarodowych ${ }^{1}$ będzie można od-

1 Jednym z krytyków koncentrowania uwagi na poziomie jednostki w polityce światowej, zwłaszcza na jego psychologicznych uwarunkowaniach, był K.W. Waltz. Wskazywał, że argumenty natury psycho- 
powiedzieć na to pytanie w odmienny sposób, w różnych okresach historycznych. Omawiając zagadnienie poziomu jednostkowego decydenta $\mathrm{w}$ analizie polityki zagranicznej, warto zwrócić uwagę na wielość opracowań, w których autorzy mierzyli się z politycznym przywództwem, jego kategoriami, uwarunkowaniami, traktując ten kierunek badań jako dyscyplinę naukową ze swoim wyodrębnionym przedmiotem badań i metodologią [Rhodes 2014: 5-7].

Przywództwo w najszerszym znaczeniu wiąże się z ludzkim działaniem, „przywódcy wyznaczają bądź wyjaśniają cele grupie lub poszczególnym jednostkom, by wspólnie je realizować, osiągać" [Keohane 2010: 23], przywództwo polityczne pozostaje istotnym jego przykładem. W studiach nad przywództwem politycznym są analizowane kategorie łączone z przywództwem, takie jak: siła i władza. Wiązanie przywództwa $z$ siłą i pozycją lub nawet synonimiczne stosowanie tych dwóch pojęć wynika z faktu, że niejednokrotnie przywódcy koncentrują swoje wysiłki na zdobywaniu władzy, jakkolwiek należy pamiętać o tych jednostkach, które obejmowały stanowiska utożsamiane ze sprawowaniem rządów, nie będąc przywódcą [Keohane 2014: 26].

Część autorów, którzy jednostkę sytuują centralnie w prowadzonych badaniach, rozpoczyna swoje rozważania od pracy Niccolo Machiavelliego, uznając go za pioniera studiów nad przywództwem, który umiejętnie połączył studium przypadku z ogólnym przeglądem determinantów, wyznaczników przywództwa [Gardner 1989]. Nie można jednak pominąć wcześniejszych rozpraw Platona i Arystotelesa czy wreszcie Tukidydesa, rozpatrujących ten koncept w nawiązaniu do indywidualnych cech przywódcy. W kolejnych okresach historycznych kategoria przywództwa i jego różnej natury uwarunkowań stanowiła przedmiot badań dla coraz szerszego kręgu badaczy: filozofów, historyków, politologów, wreszcie psychologów [Foley 2014: 33].

Obszerna literatura poświęcona studiom nad przywództwem politycznym determinuje wielość podejść do tego zagadnienia. Na gruncie nauki anglosaskiej można wskazać cztery podstawowe nurty badawcze [Wilczyńska, Juja 2011]. Po pierwsze, nurt psychologiczno-osobowościowy, w ramach którego źródeł przywództwa upatruje się w określonych, na ogół wybitnych cechach jednostki. Po drugie, podejście interakcyjne odnosi się do przewodzenia jako relacji pomiędzy przywódcą a resztą społeczeństwa. Podejście trzecie to nurt instytucjonalny, w którym przywództwo jest rozpoznawane jako zespół określonych, zrutynizowanych działań, w ramach których są realizowane role i działają odpowiednie formuły postępowania zależne od kontekstu. Po czwarte, sytuacjonizm szuka źródeł przywództwa w określonej konfiguracji czasów, miejsc i zdarzeń, od których zależy zapotrzebowanie na odpowiedni typ przywództwa. W badaniach empirycznych nie sposób pominąć studiów przypadków, ze szczególnym uwzględnieniem reżimów totalitarnych albo badań

logicznej są zbyt ogólne, aby przesądzać o przebiegu zjawisk społecznych, podnosił, że przenoszenie twierdzeń z poziomu jednostki na poziom sytemu ma charakter redukcyjny [por. Waltz 1959: 28-31]. 
porównawczych. Jednak jak wskazali Ludger Helms i Guy Peters [Helms, Peter 2012: 26-29], skoncentrowanie analizy na jednym przykładzie nie zawsze stanowi istotny wkład $\mathrm{w}$ dyscyplinę studiów nad przywództwem. $\mathrm{Z}$ tego powodu część autorów zdaje się zmierzać w kierunku tzw. holistycznego podejścia do badań, akcentującego wielowymiarowość i wieloczynnikowość. Wielość podejść i modeli w ramach studiów nad przywództwem to kolejna z inherentnych cech tej dyscypliny.

Celem artykułu jest próba konceptualizacji poziomu jednostki w analizie polityki zagranicznej z wykorzystaniem kategorii i narzędzi stosownych w badaniach nad poznawczymi uwarunkowaniami przywództwa politycznego. W pierwszej części zostanie przedstawiony zarys pojęcia przywództwa, przy odwołaniu do bogatej literatury podejmującej to zagadnienie. W dalszej kolejności zostaną omówione ramy teoretyczne analizy polityki zagranicznej, w tym również poziomy tej analizy. Stosownie do podjętego zagadnienia część rozważań zostanie poświęconych narzędziom analizy właściwym dla poziomu pojedynczego decydenta. W tej części zostaną omówione m.in. podejście klasyfikujące style przywództwa w polityce zagranicznej, narzędzie kodu operacyjnego ${ }^{2}$.

Wydaje się, że w analizie polityki zagranicznej, przy uwzględnieniu jej cech: złożoności i kompleksowości, pomocne może się okazać sięgnięcie po zróżnicowany zestaw narzędzi heurystycznych, zwłaszcza gdy przyjąć, że istnieje potrzeba stworzenia wielowymiarowych modeli, uwzględniających poza płaszczyzną systemową, a zwłaszcza narodową, także poziom indywidualnego decydenta. Próby zastosowania podejść poznawczych w studiach nad przywództwem oraz w analizie zachowań jednostek w polityce zagranicznej nie są nowe ${ }^{3}$, jednak stale narażone na krytykę, która często wiąże się z argumentem redukcyjności twierdzeń albo z ograniczonymi poznawczymi możliwościami tego typu analizy. Interdyscyplinarność w badaniach nad poziomem jednostki w polityce zagranicznej wynika z zastosowania $\mathrm{w}$ analizie tej polityki kategorii związanych ze studiami nad przywództwem, ale również modeli, np. osobowościowych, formowanych w ramach psychologii politycznej, co w efekcie może pozwolić na większą niż dotychczas weryfikowalność wspomnianych twierdzeń.

2 Szerzej na temat Kodu operacyjnego i jego ewolucji, z zastosowaniem studium przypadku, A. Umińska-Woroniecka, Siła przekonań - zastosowanie kodu operacyjnego w analizie polityki zagranicznej, „Stosunki Międzynarodowe - International Relations” 2017, nr 1 (53), s. 131-148.

3 Do grona badaczy próbujących ustalić, na jakich warunkach, w jaki sposób i w jakim stopniu w różnych teoriach stosunków międzynarodowych, m.in. w ramach realizmu, realizmu strukturalnego, instytucjonalizmu, konstruktywizmu, są uwzględniane odmienne kategorie teorii psychologicznych, należą: R. Jervis, A. George, H. C. Kelman. Współcześnie to zagadnienie jest kontynuowane w pracach P. Tetlocka [por. Tetlock 2001: 67-92; 1999: 399-401]. 


\section{PRZYWÓDZTWO POLITYCZNE - ZAGADNIENIA DEFINICYJNE}

Ramę teoretyczną dla analizy poziomu aktora w polityce zagranicznej, identyfikowanego na potrzeby tego wywodu jako pojedynczego decydenta politycznego, stanowi kategoria przywództwa politycznego oraz narzędzia właściwe dla badania poziomu jednostki $\mathrm{w}$ analizie polityki zagranicznej. $\mathrm{Z}$ tego powodu pierwszym krokiem w konceptualizacji podjętego zagadnienia będzie sięgnięcie do pojęć wypracowanych w ramach studiów nad przywództwem politycznym.

Przywołując klasyczny już dzisiaj interaktywny model przywództwa politycznego Roberta Elgie'go, który stanowi swoistą kombinację osobistych i instytucjonalnych aspektów przywództwa, można ujmować tę funkcję jako udział w procesie decyzyjnym, który jest warunkowany przez przywódcę, a ten ostatni posiada zdolność oddziaływania na środowisko, w którym operuje, i odwrotnie [Elgie 1995: 7]. Innymi słowy dochodzi do wielopoziomowych interakcji, w ramach których przywódca może w jakimś stopniu implikować środowisko, a jednocześnie to środowisko struktura - oddziałuje na przywódcę. W przywołanym modelu jednostka-decydent - aktywnie kształtuje proces decyzyjny, co stanowi również centralne zagadnienie $\mathrm{w}$ analizie polityki zagranicznej.

Jean Blondel, odwołując się do wspomnianej już wyżej kategorii siły [Blondel 1987: 3-6], wskazał, że przywództwo polityczne, ,co jest oczywiste, stanowi zasadniczo fenomen władzy: mamy do czynienia z siłą, której przejawem jest możliwość implikowania przez jednostkę lub nawet grupę pozostałych do działań (pozytywnych lub negatywnych), albo przynajmniej do ich kontynuacji". Zdaniem tego autora, takie rozumienie przywództwa politycznego jest niewystarczające, jeżeli nie towarzyszy mu ustalenie, co jest „źródłem siły” lidera lub liderów? Jakimi instrumentami, sposobami są w stanie oddziaływać na innych? Wreszcie, zdaniem autora, najbardziej istotne ustalenie, czy obecność przywódcy ma jakiekolwiek znaczenie? By udzielić odpowiedzi na te pytania, Jean Blondel nakazał uwzględnić wiele okoliczności i czynników, wśród których za jeden z ważniejszych uznał środowisko (otoczenie), w którym lider ma działać. To właśnie struktura środowiska warunkuje, a nawet pozwala na kształtowanie liderów [Blondel 1987:15]. Autor podkreślił również znaczenie cech osobowościowych lidera i ich potencjalne źródło. Wreszcie zwrócił uwagę na tzw. instytucjonalne instrumenty, narzędzia, które mogą pomóc bądź udaremnić działania przywódcy. W ten sposób uwidocznił wpływ czynników osobowych oraz instytucjonalnych na przywództwo polityczne. Jego zdaniem w kontekście psychologicznym istotne są zwłaszcza cechy charakteryzujące przywódcę politycznego oraz ustalenie tego, w jaki sposób cechy te wpływają na jego zachowanie. Za dwa kluczowe dla przywódcy politycznego atrybuty uznał trwałość, co oznacza, że przywódcą jest się nie przez krótką chwilę, ale przez pewien czas, oraz strategiczny charakter decyzji podejmowanych przez przywódcę. Jerzy Sielski [2013: 95] zaproponował, by dołączyć dodatkowe dwie cechy: posiadanie odpowiedniego zaplecza politycznego i zajmowanie najwyższego stanowiska w danym układzie politycznym. 
Na bliski związek przywództwa politycznego i siły wskazał Ludger Helms, jednocześnie podkreślając, że nie są to synonimy [Helms 2012: 3]. Relacja pomiędzy przywództwem, zwłaszcza politycznym, i siłą, jest złożona i ma wiele wymiarów. Także wtedy gdy uwzględnimy upowszechnione na szeroką skalę w teorii stosunków międzynarodowych w ostatnich dwóch dekadach dychotomię tzw. soft power i hard power. Jego zdaniem, konsekwencją zróżnicowania podejść i rozumienia przywództwa, szczególnie przywództwa politycznego, jest brak konieczności jednolitego ujęcia tego konceptu ${ }^{4}$.

Omawiając kategorię przywództwa politycznego, nie sposób pominąć podstawowej typologii przywódców politycznych autorstwa Harolda Lasswella, której kryterium różnicowania pozostaje preferowany przez przywódcę sposób działania [Lasswell 1960: 264]. W przywołanej typologii mamy zatem do czynienia z trzema podstawowymi typami przywódczymi: administratora, agitatora oraz teoretyka. Ten pierwszy zasadniczo koncentruje swoje działania na mobilizowaniu ludzi, drugi skupia swoją aktywność na oddziaływaniu przez system, instytucje, natomiast ostatni - teoretyk, kreując ideologię społeczno-polityczną, wyznacza wartości, do których należy dążyć. Lasswell w przedstawionej typologii odwołuje się do osobistych „preferencji”, ponieważ to określone cechy osobowościowe nadają przywódcy charakter agitatora, administratora czy też teoretyka, predysponując go do odgrywania określonej roli zależnie od środowiska, w którym operuje. Preferencje przywódcy determinują nie tylko decyzje, ich treść, sposób podejmowania, ale również strategie implementowania decyzji. Przyjmując jako kryterium preferencje jednostki co do sposobu wdrażania decyzji, Urszula Jakubowska wyodrębniła dwie kategorie przywódców: manipulatorów i protagonistów [Jakubowska 2001: 42]. Pierwsza kategoria preferuje działalność zakulisową, unikając eksponowania swojej osoby publicznie, stara się pozyskać zwolenników niejawnie, ukrywając rzeczywiste cele swoich zamierzeń. Protagoniści dążą do jawności swoich działań, „wypowiadają się publicznie, przekonują, mediują, reformują" [Jakubowska 2001: 43]. Jak podniosła autorka, te dwa sposoby działań mogą być stosowane zintegrowanie i znajdować odzwierciedlenie w strategii jednego przywódcy.

Z punktu widzenia poruszanego zagadnienia za kluczową należy uznać kategorię przywództwa politycznego, w którym przywódca polityczny [Hartliński 2012: 21] podejmuje decyzje w sferze polityki zagranicznej (zasadniczo na każdym etapie

${ }^{4}$ Systematyzację podejść do kategorii przywództwa politycznego przedstawił Przemysław Żukiewicz, akcentując trudność zastosowania pojedynczego podejścia badawczego. Jego zdaniem, możliwe jest zastosowanie więcej niż jednego paradygmatu (w odniesieniu do jego badań zastosowanie znajduje nurt neoinstytucjonalny oraz teoria społecznej identyfikacji). Odwołując się do tych dwóch nurtów/podejść, „,przywództwo polityczne to proces społeczny, w którym członek społeczności dobrowolnie udziela poparcia politycznego (angażuje się bezpośrednio w pracę na rzecz popieranego lub w wyborach oddaje na niego głos) innemu członkowi społeczności, ponieważ uznaje go za aktualnie najpełniej odpowiadającego społecznemu wyobrażeniu o ideale lidera oraz mającego największe szanse na zrealizowanie określonych celów podzielanych przez nich obu" [Żukiewicz 2011: 73]. 
tego procesu), funkcjonując $w$ ramach zinstytucjonalizowanego systemu organów państwa. Zakładając, że polityka zagraniczna jest procesem decyzyjnym, w którym są zaangażowane jednostki, w obszarze zainteresowań będą się znajdować w pierwszej kolejności podmioty uczestniczące $\mathrm{w}$ tym procesie, ze szczególnym uwzględnieniem głów państw, szefów rządów i ministrów spraw zagranicznych. To prowadzi do zorientowania na tzw. model decyzyjny, jako podstawowy dla prowadzonych rozważań, który bierze również pod uwagę styl podejmowania decyzji, od autokratycznego, przez konsultacyjny do demokratycznego. Podstawową zmienną, oddziałującą na zachowania (decyzje) ma być tutaj informacja [Żukiewicz 2011: 54], którą dysponuje przywódca - decydent, jednak realne jej wykorzystanie, zwłaszcza w sferze polityki zagranicznej, może być dodatkowo warunkowane całym zbiorem czynników, w tym jego możliwości poznawczych i osobowości ${ }^{5}$.

\section{POLITYKA ZAGRANICZNA - ISTOTA I POJĘCIE}

W tym miejscu warto przedstawić kilka uwag dotyczących zdefiniowania polityki zagranicznej. Należy podkreślić, że brakuje jednej powszechnie obowiązującej definicji polityki zagranicznej. Za dominującą należy uznać państwowo-centryczną definicję, zgodnie z którą polityka zagraniczna stanowi część ogólnej polityki państwa, która jakkolwiek jest kształtowana w jego systemie wewnątrzpaństwowym, to jednak realizuje się w systemie międzynarodowym [Zięba 2004]. Nawiązując do definicji Teresy Łoś-Nowak, która ujęła politykę zagraniczną jako dynamiczny proces formułowania i realizacji interesów narodowych i celów polityki w poliarchicznym środowisku międzynarodowym, zwraca uwagę sekwencyjny charakter tego procesu, w którym występują kolejno fazy: identyfikacji i formułowania interesów państwa i narodu oraz implementacji polityki zagranicznej [Łoś-Nowak 2011: 47] .

Niektórzy z autorów dokonują rozszerzenia podmiotowego kategorii polityki zagranicznej, nadal jednak za głównego aktora uznając państwo. Przykładem może być tutaj ujęcie, zgodnie z którym polityka zagraniczna to suma oficjalnych zagranicznych stosunków prowadzonych przez niezależne podmioty (zwykle państwa) w stosunkach międzynarodowych [Hill 2003: 3]. Autor tej definicji Christopher Hill w jednym z ostatnich opracowań, w którym przeanalizował kategorię interesu narodowego, zwrócił uwagę na tzw. społeczny kontekst polityki zagranicznej, związany m.in. z etnicznym, kulturowym zróżnicowaniem. To spowodowało jego

\footnotetext{
5 Warto wspomnieć o typologii osobowości przywódców zaproponowanej przez Jerzego Wiatra, który wskazując na różne kryteria odniesień dotyczących władzy, wyróżnił m.in.: charyzmatyków, reprezentantów, kompromisowych, fanatyków, otwartych, dogmatyków, ideologów, pragmatyków [Wiatr 1980].

6 Za kategorię pierwotną wobec procesu polityki zagranicznej niektórzy z autorów uznają interesy państwa, w tym ujęciu polityka zagraniczna będzie ,procesem formułowania i realizacji celów, środków i metod, wynikających z zewnętrznej funkcji państwa i odzwierciedlających jego interesy”. Cele, metody i środki będą miały charakter konsekutywny wobec interesów państw [por. Pietraś 1978: 14].
} 
zdaniem konieczność rozpatrywania procesu konstytuowania polityki zagranicznej w zewnętrznym i wewnętrznym wymiarze już na etapie formułowania celów.

Polityka zagraniczna rozpatrywana w kategoriach procesu decyzyjnego [Sulowski 2011: 298; Dudek 2012] obejmuje całą sekwencję decyzji uprawnionych organów podejmowanych $w$ fazach formułowania oraz implementacji. Tym tropem podążyła w swoich badaniach Valerie Hudson, według której polityka zagraniczna to strategia wybierana przez rządy państw narodowych dla osiągania celów w stosunkach z innymi podmiotami [Hudson 2012: 12]. Natomiast celem analizy polityki jest wyjaśnienie zachowań decydentów, działających pojedynczo lub w grupie. Konkludując, polityka zagraniczna jest procesem decyzyjnym, o charakterze teleologicznym (nastawionym na realizację celu) i procesualnym (dynamicznym i zmiennym) [Dyduch 2016: 37], w której na etapach formułowania i realizacji uczestniczą jednostki ludzkie.

\section{ANALIZA POLITYKI ZAGRANICZNEJ - ISTOTA, GENEZA I POZIOMY}

Analiza polityki zagranicznej może być ujmowana jako subdyscyplina stosunków międzynarodowych ${ }^{7}$, która koncentruje się na wyjaśnianiu polityki zagranicznej, nawiązując do teoretycznych założeń i twierdzeń na temat ludzkich zachowań jednostek bądź grup [Hudson 2012: 14-25]. Innymi słowy znajduje się na przecięciu wiedzy teoretycznej o stosunkach międzynarodowych z praktyką międzynarodowego życia politycznego [Sajduk 2009: 59-86], przy uwzględnieniu teoretycznych paradygmatów na temat zachowań decydentów. W każdym wypadku niezbędnym komponentem tak rozumianej analizy jest zestawienie teoretycznych założeń z badaniem praktyki politycznej, która może się koncentrować na danym przykładzie (studium przypadku) albo uwzględniać grupę podmiotów (np. analiza porównawcza).

Analiza polityki zagranicznej, a konkretnie - podejmowany w jej ramach problem aktora-struktury (the agency-structure problem) [Wendt 1987: 335-370] ma swoje źródło w zapoczątkowanej w wiekach średnich dyskusji o zróżnicowaniu między jednostką a państwem. Współcześnie zagadnienie to pozostaje przedmiotem dyskusji w wymiarze metateoretycznym w naukach społecznych. Rozważania skoncentrowane na jednostce w stosunkach międzynarodowych odwołują się do podejmowanych we współczesnej nauce dychotomii między aktorem i systemem, częścią i całością, indywidualizmem i holizmem [Carlsnaes 1992: 245-270]. Aktor-struktura, ich wzajemne powiązania [Archer 2003] i różnice to problem obecny również w wybranych paradygmatach stosunków międzynarodowych, jednak warto podkreślić, że za kluczowe można uznać zróżnicowanie ontologiczne w rozumieniu

7 W polskiej nauce o stosunkach międzynarodowych pojawia się postulat, zgodnie z którym analiza polityki zagranicznej posiada status wyodrębnionego obszaru badawczego, nie zyskując tym samym statusu subdyscypliny - z wystąpienia prof. Marka Pietrasia, Konwencja Polskiego Towarzystwa Studiów Międzynarodowych, Łódź 9-10 listopada 2016. 
struktury czy jej immanentnych cech. Uwypuklenie sprawczego działania jednostki lub grupy ludzi stanowi centralny problem we współczesnej analizie polityki zagranicznej. To implikuje dalsze pytania badawcze dla tej subdyscypliny - np. kto jest zaangażowany w proces kształtowania i prowadzenia polityki zagranicznej i jakie to ma skutki dla wyjaśnienia tej polityki - ma również bezpośredni związek z konstrukcją metodologiczną poziomów analizy polityki zagranicznej ${ }^{8}$.

Warto w tym miejscu podkreślić, że analiza polityki zagranicznej nie jest równoznaczna z teorią (bądź teoriami) polityki zagranicznej, ta bowiem, zdaniem niektórych autorów, nadal pozostaje w fazie kształtowania ${ }^{9}$. Na potrzebę powstania teorii polityki zagranicznej wskazywał jeszcze w 1980 roku James Rosenau, który podnosił, że dotychczasowy ,brak teorii w badaniach nad polityką zagraniczną nie może być łatwo uzasadniony, czy w prosty sposób wytłumaczalny" [Rosenau 1980: 115-169].

Początki kształtowania się analizy polityki zagranicznej sięgają lat 50. i 60. ubiegłego wieku, kiedy powstały trzy paradygmatyczne prace amerykańskich badaczy, dając tym samym teoretyczne podwaliny tej subdyscypliny. Każda z nich, jakkolwiek z innej perspektywy, wprowadzała do badań wymiar wewnątrzkrajowy, dotychczas na ogół pomijany w studiach nad polityką zagraniczną, czego przykładem były funkcjonujące dotychczas ujęcia polityki międzynarodowej w kategoriach kul bilardowych czy tzw. black box. Przywołane prace stały się zarzewiem wykształcenia głównych nurtów badawczych w analizie polityki zagranicznej państwa.

Pierwszy z nich został zainspirowany publikacją z 1954 roku, której autorzy - Richard Snyder, Burton Sapin oraz Henry W. Bruck- podjęli próbę wyjaśniania polityki zagranicznej, traktując państwa jako jednolite, homogeniczne podmioty, których zasoby oraz „natura” mają koherentny charakter [Snyder, Sapin, Bruck 1954: 62]. Jednocześnie za centralną kategorię, umożliwiającą wyjaśnienie polityki zagranicznej jednorodnych państw, uznali proces decyzyjny, który jest warunkowany nie tylko działaniami innych (zewnętrznych wobec państwa) podmiotów (innych państw), lecz także w równym stopniu czynnikami wewnętrznymi, np. organizacją w ramach biurokratycznych struktur państwa w jej różnych aspektach. Koncentrując swoje rozważania na podejściu procesu decyzyjnego do analizy polityki zagranicznej,

${ }^{8}$ Następstwem wielości podejść w analizie polityki zagranicznej jest również ich hybrydyzacja, czego przykładem może być tzw. poliheurystyczna teoria procesu decyzyjnego w polityce zagranicznej (the poliheuristic theory of foreign policy decision making). Proponuje ona dwupoziomowy model analityczny, będący kombinacją dwóch ujęć w analizie polityki zagranicznej. Jak wskazał jej prekursor Alex Mintz, stanowi ona swoisty pomost pomiędzy poznaniem (wyrażanym zwłaszcza w tzw. podejściu poznawczym) oraz racjonalnością (werbalizowaną przez podejście procesu decyzyjnego). Innymi słowy teoria poliheurystyczna koncentruje się na wyjaśnieniu „dlaczego" i ,jak” podejmowane są decyzje, co czyni teorię odpowiednią zarówno do treści, jak i procesów decyzyjnych. W równym stopniu akcentował ważność zarówno całego procesu, jak i jego wyniku [zob. szerzej: Mintz 2002].

9 [Por. Stemplowski 2015: 31-45]. Inna perspektywa: ,Przy uwzględnieniu dotychczasowych wysiłków zmierzających do nakreślenia teoretycznych ram fenomenu, jakim jest polityka zagraniczna, wydaje się, że ma ona cechy tzw. integralnej teorii szczegółowej, bowiem struktura przedmiotu badań jest złożona nie tylko pod względem ilościowym (liczby składników), ale również pod względem jakościowym (nietożsamość jakości elementów i jakości całości)" [zob. szerzej: Karwat 2011]. 
zdefiniowali go jako proces dokonywania wyboru przez decydenta jednego wariantu spośród kilku możliwych, mającego prowadzić do takiego stanu rzeczy, który byłby pożądany w przyszłości przez podejmujących decyzję. Decydenci kierują się całym katalogiem przesłanek, począwszy od funkcji i celów całego systemu decyzyjnego, przez przyjęte normy i wartości, aż do osobowości. Przez tę ostatnią autorzy rozumieli intelektualne umiejętności decydentów, sposoby ich wykorzystania, interpretowanie własnych kompetencji oraz typ osobowości politycznej.

To podejście określane mianem procesu decyzyjnego doczekało się swoich kontynuatorów, przykładem było m.in. studium Grahama Allisona o kubańskim kryzysie rakietowym w 1962 roku. W swojej publikacji Allison wskazał na trzy różne sposoby rozumienia podejmowania decyzji, z których pierwsze określane mianem „,racjonalnego aktora" miało dać odpowiedź na pytanie, jakie decyzje mogą być najbardziej użyteczne przy założeniu, że każdy rząd zmierza do maksymalizacji użyteczności swoich decyzji. Użycie w odniesieniu do pierwszego z podejść pojęcia racjonalnego aktora może sugerować, że pozostałe dwie cechy racjonalności nie posiadają [Allison 1971: 144]. Dlatego kolejny zaproponowany przez Allisona model - polityka biurokratyczna - odrzuca tezę o biurokratycznym podejmowaniu decyzji jako procesie racjonalnym. Decyzja to w istocie efekt wzajemnej rywalizacji o pozycję i władzę w ramach struktur biurokratycznych. Natomiast trzecie podejście - model procesu organizacyjnego - odnosi się do organizacji wdrażającej zaplanowane procedury lub standardowe sposoby działania. Alisson przy analogicznym do modelu SBS założeniu o unitarnym charakterze aktora - państwa, wskazał na możliwość wykorzystywania $\mathrm{w}$ analizie równocześnie trzech proponowanych przez siebie modeli [Allison 1969: 700-703].

Kolejny nurt w badaniach nad polityką zagraniczną wyznaczyła pionierska praca wspomnianego już Jamesa Rosenau. Głównym założeniem tej pracy było zbudowanie ogólnej teorii, która uwzględniając wiele zmiennych, znalazłaby swoje zastosowanie do wyjaśniania polityki zagranicznej państw w perspektywie porównawczej. Rosenau wyodrębnił wiele potencjalnie możliwych źródeł decyzji w polityce zagranicznej i podzielił je na pięć podstawowych kategorii, określając je jako zmienne: specyficzne, związane z rolą, rządowe, społeczne i systemowe. Praca Rosenau nadała początek całemu kierunkowi w analizie polityki zagranicznej (Comparative Foreign Policy - CFP). Podejście komparatystyczne zdominowało na kilka dekad analizę polityki zagranicznej, wychodziło bowiem niejako naprzeciw oczekiwaniom badaczy do stworzenia wielopoziomowej analizy, w której możliwe stało się zagregowanie i porównanie zmiennych determinujących politykę zagraniczną. Pozwoliło na stworzenie schematów, konstruowanych z użyciem zmiennych skorelowanych ze sobą. James Rosenau dokonał kilka dekad później rewizji swoich założeń, uwzględniając proces transnarodowości współzależności w środowisku międzynarodowym [Rosenau 1984: 245-305].

Z perspektywy podjętego zagadnienia na szczególną uwagę zasługuje ostatni z kierunków. Został on zainicjowany przez Margaret i Harolda Sprout, którzy za- 
proponowali wyodrębnienie dwóch płaszczyzn, w których funkcjonuje decydent (jednostka ludzka bądź grupa) oraz są podejmowane decyzje w polityce zagranicznej. Ich zdaniem, decydent poza tzw. środowiskiem operacyjnym (sferą operacyjną - rzeczywistością), w którym działa, jednocześnie funkcjonuje w tzw. sferze psychologicznej (percepcji, wyobrażeń, ocen i oczekiwań). Nacisk na indywidualnego decydenta doprowadził do uwzględnienia, na niespotykaną dotąd skalę, czynników psychologicznych i poznawczych, jako zmiennych wyjaśniających wybory dokonywane przez pojedynczych decydentów w ramach polityki zagranicznej. Kierunek ten w analizie polityki zagranicznych podjęło wielu badaczy, zwłaszcza z kręgu nauki amerykańskiej. Zdaniem Ryszarda Zięby, mimo że wielu z nich podąża tropem wskazówek sformułowanych przez Harolda i Margaret Sprout [1957: 309-328], to „stwierdzić należy, iż proste rozdzielenie sfery psychologii i rzeczywistości (sfery operacyjnej) nie ułatwia poznania naukowego" [Zięba 2005: 18].

Wymienione prace, dające początek analizie polityki zagranicznej, łączył jeden wspólny mianownik - założenie, że za procesami decyzyjnymi i wyborami, które są dokonywane w ramach lub w związku z polityką zagraniczną, stoją ludzie, którzy operują w określonym środowisku. Natomiast różnica między nimi sprowadza się do poziomu prowadzonej analizy.

W analizie polityki zagranicznej zasadniczo są wskazywane trzy poziomy, które bezpośrednio nawiązują do poziomów analizy polityki międzynarodowej stanowiącej propozycję Kennetha Waltza: poziom jednostki ludzkiej, poziom państwa i jego systemu politycznego i ekonomicznego oraz poziom systemu międzynarodowego [Waltz 1959: 6-12]. Z punktu widzenia prowadzonych rozważań na uwagę zasługują dwa pierwsze, ponieważ - jakkolwiek w innej pespektywie - uwzględniają w znacznym stopniu wewnątrzkrajowe wyznaczniki kształtowania i prowadzenia polityki zagranicznej, pozwalają uchwycić tę politykę w kategoriach decydowania (przez jednostkę lub grupę), warunkowanego przez wiele zmiennych. Także wspomniane wyżej trzy podejścia do analizy polityki zagranicznej koncentrują się odpowiednio na poziomie państwa: pre-teoria Rosenau oraz model Snydera, Brucka i Sapina (SBS), a także w przeważającej mierze na poziomie jednostki - podejście przedstawiane przez małżeństwo Sprout. Jak wskazywał J. David Singer, przyjęcie różnych od systemu międzynarodowego poziomów analizy polityki zagranicznej, a zwłaszcza poziomu jednostki, wprowadza potrzebę rozpoznania trudnych do uchwycenia atrybutów, jak: percepcja, doświadczenie czy osobowość [Singer 1961: 91-92]. To jednak nie powinno, zdaniem tego autora, odwodzić od analiz na poziomie państwa albo jednostki, ponieważ mogą one zapewnić bogatszy opis, zwiększając możliwości wyjaśniające i predykcyjne ${ }^{10}$.

\footnotetext{
${ }^{10}$ Jakkolwiek w polskiej literaturze stosunków międzynarodowych pojawiają się propozycje, by odstąpić od tego rodzaju koncepcji poziomów i wykluczyć poziom jednostki, a wyodrębnić np. poziom transnarodowy [por. Haliżak, Pietraś 2013: 11-14].
} 


\section{NARZĘDZIA BADAWCZE DLA POZIOMU JEDNOSTKI W ANALIZIE POLITYKI ZAGRANICZNEJ - OD PODEJŚCIA POZNAWCZEGO DO MODELU OSOBOWOŚCIOWEGO W ANALIZIE POLITYKI ZAGRANICZNEJ}

Struktura tej części rozważań odwołuje się do układu książki pod redakcją Stefano Guzziniego i Waltera Carlsnaesa [Guzzini, Carlsnaes 2011], którzy lokują podejście poznawcze, w tym także kod operacyjny Alexandra George'a oraz podejście modelu osobowościowego, jako narzędzia przydatne w analizie polityki zagranicznej na poziomie indywidualnego decydenta.

Znaczenie sfery poznawczej i emocjonalnej w decydowaniu w polityce zagranicznej dostrzegał Robert Jervis [Jervis 1976: 13-29]. Jego zdaniem psychologiczna dyspozycja lidera, granice poznawcze w sytuacji natłoku informacji dostępnych dla decydentów i ich skłonności do wybierania opcji politycznych przyczyniają się do niedoskonałych rezultatów polityki zagranicznej. W swoim studium podjął się wyszczególnienia mechanizmów przyczynowych prowadzących do błędnych spostrzeżeń, warunków, w których błędne spostrzeżenia najczęściej występują, rodzajów jednostek, które są z największym prawdopodobieństwem podatne błędnej percepcji. Analizując mechanizm powstawania błędnej percepcji, wyjaśniał ją jako efekt koncentracji decydenta głównie na zagrożeniach, będących wynikiem anarchiczności środowiska międzynarodowego. Mechanizm błędnej percepcji w równym stopniu mógł być warunkowany wyobrażeniami decydenta o otaczającym go świecie, które są kształtowane przez jego dotychczasowe doświadczenia, także te z najwcześniejszego okresu życia. Jak podkreślił, uwarunkowania poznawcze mogą prowadzić do selektywnego wyboru informacji dotyczących sytuacji międzynarodowej, a w efekcie do błędnych decyzji w polityce zagranicznej. Jego zdaniem przywódcy popełniają błędy w rozpoznawaniu potencjału i intencji swoich przeciwników. R. Jervis przedstawił wszechstronną syntezę teorii i dowodów eksperymentalnych pochodzących z wielu czołowych ujęć w psychologii społecznej. Za jego wkład w subdyscyplinę należy uznać wyraźne dostrzeżenie mocy wyjaśniającej modeli systemowych lub opartych na polityce wewnętrznej dla rezultatów analizy psychologicznej w polityce zagranicznej.

Dla podejścia poznawczego kluczowe znaczenie miały obok wspomnianej już pracy Roberta Jervisa, publikacje Ole Holstiego, a także Alexandra George'a [George 1969: 197-201]. Obaj autorzy poruszyli w swoich pracach zagadnienie kodu operacyjnego (operational code), najprościej ujmując - systemu przekonań decydenta o naturze historii, polityki, działania politycznego i wreszcie konfliktu [Umińska-Woroniecka 2017: 138-143]. Zdaniem George'a, przekonania jednostek są współzależne, logicznie zgodne, zorganizowane hierarchicznie wokół niewielkiego zbioru „nadrzędnych przekonan” i zasadniczo odporne na zmianę. Filarami kodu operacyjnego decydenta politycznego są przekonania filozoficzne, które mogą zostać ustalone przez udzielenie odpowiedzi na pięć pytań dotyczących natury polityki (np. czy jest ona płaszczyzną konfliktu czy współpracy), oraz przekonania instrumentalne. 
Przekonania instrumentalne dotyczą skuteczności strategii służących realizacji własnych interesów, innymi słowy odnoszą się do relacji pomiędzy celami a środkami, które pozwalają na ich urzeczywistnienie. Szczególnie ważnym komponentem kodu operacyjnego jest postrzeganie wroga $\mathrm{z}$ tego względu, że to właśnie dotychczasowy system przekonań jednostki najmocniej oddziałuje na obserwację i interpretację informacji, w tym na rozpoznawanie elementów rzeczywistości uznanych przez decydenta za zagrożenie. Zgodnie z założeniami George'a, ludzie wykazują silną tendencję, by dostrzegać to, co na podstawie swoich dotychczasowych przekonań spodziewają się zobaczyć. Innymi słowy są bardziej wyczuleni na te informacje, które są zgodne z ich wcześniejszymi przekonaniami, aniżeli na te, które są z przekonaniami sprzeczne. Wybiórcza selekcja informacji prowadzi do uporczywości przekonań, a tendencyjność systemu przekonań ma swoje konsekwencje dla polityki zagranicznej, zwłaszcza w sposobie postrzegania przeciwników i zagrożeń, które w efekcie mogą prowadzić do pogrzebania ewentualnych szans zażegnania konfliktu. Przekonania filozoficzne mogą prowadzić do sytuacji, w której lider podejmuje działania zmierzające do ochrony treści tych przekonań przed arbitralną zmianą. Przekonania te mogą z upływem czasu stać się częścią kultury politycznej elit, która systematycznie może być transformowana przez nowych liderów. Autor zalecał, by w ramach działań analitycznych koncentrować się na tych przekonaniach jednostki, które mogą być wywnioskowane przez badacza na podstawie różnego rodzaju danych oraz możliwości obserwacyjnych. Podniósł fakt, że system przekonań jako taki może podlegać pewnym modyfikacjom wynikającym z osobowości lidera, przywołując jako przykład dwa różne typy osobowościowe przywódców Związku Radzieckiego: Stalina i Chruszczowa. Stwierdził, że zachowania pierwszego z nich wynikały w zasadniczej mierze z jego systemu przekonań, a częściowo z jego cech osobowościowych.

Zaproponowane przez A. George'a narzędzie analityczne w postaci kodu operacyjnego podlegało zrewidowaniu w pracach takich badaczy, jak: Ole Holsti [1967: 16-39], Robert Jervis [1974: 17] czy Jack Levy, którzy na pierwszy plan w swoich badaniach wysunęli obok tendencyjności zagadnienia konfliktu i zagrożenia. Natomiast kategoria modelu osobowościowego lidera $\mathrm{w}$ analizie polityki zagranicznej, lakonicznie potraktowana przez George'a, doczekała się pogłębionych studiów, zwłaszcza prowadzonych przez Margaret Hermann [1998: 293-298], która łącząc narzędzia z teorii przywództwa politycznego, wyjaśniła działania decydentów w polityce zagranicznej.

Autorka, pisząc o przywództwie politycznym, zauważyła, że analiza tego zjawiska powinna uwzględniać następujące elementy:

1) osobowość i rodowód przywódcy;

2) charakterystyki grup i pojedynczych sympatyków, którym lider przewodzi;

3) właściwości więzi, łączących przywódcę z innymi, którzy podążają za nim;

4) kontekst, czyli szerszy układ społeczny, w którym jest sprawowane przywództwo; 
5) efekty konkretnych przypadków interakcji między liderem a podporządkowaną mu grupą.

Jak dowodziła A. Hermann, przywództwo zależy od charakteru i proporcji wymienionych elementów, które łącząc się w rozmaity sposób, prowadzą do zróżnicowanych rezultatów. $Z$ punktu widzenia prowadzonego wywodu warto zwrócić uwagę na złożony charakter pierwszego z przywołanych elementów. Osobowość przywódcy jest tutaj rozumiana szeroko, uwzględnia jego przekonania, sposoby reakcji na napięcia psychologiczne i presję, motywację działań, uprzedzenia, wynikające również z dotychczasowych doświadczeń. Rodowód to inaczej indywidualne doświadczenia lidera związane ze sprawowaniem przywództwa, m.in. na jakim stanowisku rozpoczynał swoją karierę, w jaki sposób kształtowała się jego droga do aktualnego stanowiska [Hermann 1998: 301-304]. Równocześnie Hermann podniosła wagę kontekstu, czyli układu społecznego, w którym przywództwo jest sprawowane. Za komponenty tego układu uznała siedem czynników, tj.: charakter procedur decyzyjnych; stopień odpowiedzialności przywódcy wobec wyborców; siłę i rodzaj opozycji; charakter wspólnych przekonań politycznych, zasoby pozostające w dyspozycji przywódcy;poziomy organizacyjne łączące przywódcę z wyborcami oraz specyfika czasów [Hermann 1986: 169; Marzęda 2002: 103].

W swoich badaniach Hermann podjęła próbę wyjaśnienia zachowań jednostek - przywódców politycznych w sferze polityki zagranicznej przy wykorzystaniu modelu osobowościowego [Hermann 1980: 7-46]. Podstawą wyodrębnienia sześciu profilów osobowościowych charakterystycznych dla przywódców politycznych decydentów, w polityce zagranicznej są zmienne, tj.: fundamentalne przekonania przywódcy o otaczającym go świecie (w tym o polityce), motywacja władzy, styl podejmowania decyzji, styl interpersonalny (styl działania). Decydują one nie tylko o stylu prowadzenia polityki zagranicznej, ale przede wszystkim o jej „zawartości”. Autorka podniosła również wagę innych czynników, w tym zmiennych sytuacyjnych, które mogą w pewnym stopniu modyfikować lub „filtrować” wpływ osobowości na zachowania polityczne, np. poziom zainteresowania decydenta - przywódcy politycznego, sprawami zagranicznymi. Za pomocą analizy treści przemówień, wywiadów i innych tekstów Hermann zbadała motywy osiągnięć, afiliacji i władzy u 45 przywódców politycznych: prezydentów i premierów, które w efekcie pozwoliły jej na wyodrębnienie wspomnianych sześciu orientacji osobowościowych przywódców w polityce zagranicznej: ekspansjonistyczną, aktywno-niezależną, orientowaną na wpływ, mediacyjno-integracyjną, oportunistyczną, rozwojową. Posługując się takimi wskaźnikami, jak etnocentryzm, niska złożoność poznawcza i nieufność, podjęła próbę wyznaczenia miary autorytaryzmu. Dodatkowo opracowała wskaźniki dwóch innych zmiennych poznawczych: wewnętrznej kontroli rezultatów i pewności siebie [Hermann 1987: 161-182].

Skonstruowana przez autorkę matryca orientacji osobowościowych wraz ze wskazaniem ich zmiennych składowych była narzędziem wykorzystanym przez innych badaczy [Kaarbo 1998: 243], zwłaszcza w studiach porównawczych. Docze- 
kała się również modyfikacji, także podejmowanych przez samą Hermann [Hermann 1994: 363-374]. Jednak na gruncie badań nad zagadnieniem przywództwa politycznego w sferze polityki zagranicznej pozostaje jedną z nielicznych metod budowania zintegrowanych profilów osobowościowych skupionych na orientacji i zachowaniach przywódców w dziedzinie polityki zagranicznej.

\section{ZAKOŃCZENIE}

Połączenie kategorii przywództwa politycznego z analizą polityki zagranicznej ma na celu próbę wyjaśnienia zachowań jednostek - decydentów - w procesie polityki zagranicznej i łączy się bezpośrednio z jednostkowym poziomem tej analizy. Eksponowanie tej kombinacji, zwłaszcza na gruncie amerykańskim [Jervis 1963: 42-51], przynosi rezultaty w postaci studiów i analiz zachowań jednostkowych decydentów w polityce zagranicznej. Analiza mechanizmów poznawczym może wskazywać na ograniczenia, które uniemożliwiają jednostkom podejmowanie działań uznanych za racjonalne. Przyjęcie założenia o wpływie cech osobowościowych na proces decyzyjny w polityce zagranicznej jest wiązane tutaj z zastrzeżeniem, że przywódcy nie działają w próżni. Stąd dla pełnego obrazu procesu decyzyjnego konieczne jest uwzględnienie elementów instytucjonalnych, organizacyjnych, środowiskowych, które mają wpływ na podejmowane w polityce zagranicznej decyzje. Odrzucenie czynników poznawczych w prowadzeniu analiz może się wiązać z różnego typu przesłankami. Po pierwsze, podjęcie konceptu jednostki w analizie polityki zagranicznej wydaje się zadaniem trudnym zwłaszcza w obliczu podnoszonego przez niektórych autorów braku walorów eksplanacyjnych dla tego podejścia. W efekcie na gruncie polskiej nauki o stosunkach międzynarodowych pojawiają się propozycje [Kostecki 2013: 122], by poziom jednostki zastąpić poziomem decyzji, w którym racjonalny aktor „określa cele i środki działania, stosownie do przyjętego modelu decyzyjnego". Po drugie mechanizmy poznawcze, tj. przekonania, emocje, cechy osobowościowe, wchodzą w „nieustanną konfigurację z czynnikami środowiskowymi" [Rapport 2017], co może prowadzić do ich zmiany, a w konsekwencji nawet stanowić barierę dla ich poznania.

Zdając sobie sprawę z tych ograniczeń, wydaje się, że istniejące narzędzia heurystyczne mogą pozwolić na analizę zachowań decydentów przy uwzględnieniu ich cech osobowościowych i mechanizmów poznawczych, ale także specyfiki rozwiązań instytucjonalnych i środowiskowych (kontekstu). Mogą również znaleźć zastosowanie $\mathrm{w}$ polskich doświadczeniach, także $\mathrm{z}$ uwagi na pojawiające się $\mathrm{w}$ ostatnich dwóch latach twierdzenia o wpływie osobowości, uprzedzeń i emocji osób uczestniczących w procesie decyzyjnym na podjęte przez nich decyzje w polityce krajowej i zagranicznej, zwłaszcza gdy przyjęte w konstytucji rozwiązania prawne w sferze uprawnień w stosunkach międzynarodowych i polityce zagranicznej nie wydają się precyzyjne. Dodatkowo teoretyczną ramę rozważań, w tym siatkę podstawowych 
pojęć, dostarczają studia nad przywództwem politycznym, a ich zestawienie z jednostkowym poziomem analizy może pozwolić na uzyskanie nowych rezultatów w rozpoznawaniu procesów decyzyjnych w polityce zagranicznej państw.

\section{BIBLIOGRAFIA}

Allison, G. 1969. Conceptual Models and the Cuban Missile Crisis, „The American Political Science Review”, vol. 63, nr 3. DOI: https://doi.org/10.2307/1954423 https://doi.org/10.1017/S000305540025853X.

Allison, G. 1971. Essence of Decision: Explaining the Cuban Missile Crisis, Little, Brown and Company, Boston.

Archer, M. 2003. Structure, Agency and the Internal Conversation, Cambridge University Press, Cambridge.

Blondel, J. 1987. Political Leadership, Sage, London-Beverly Hills.

Carlsnaes, W. 1992. The agency-structure problem in foreign policy analysis, „International Studies Quarterly", vol. 36, nr 3. DOI: https://doi.org/10.2307/2600772.

Ciechański, J. 2006, Teorie podejmowania decyzji w polityce zagranicznej, „Polski Przegląd Dyplomatyczny", nr 1.

Dudek, A. 2012. System decyzyjny w polityce zagranicznej Polski okresu tranzycji (1989-1992). Mechanizmy, procedury i instytucje, praktyka, Wydawnictwo Uniwersytetu Wrocławskiego, Wrocław.

Dyduch, J. 2016. Europeizacja polskiej polityki zagranicznej, Wydawnictwo Uniwersytetu Wrocławskiego, Wrocław.

Elgie, R. 1995. Political leadership in liberal democracies, Palgrave, New York.

Foley, M. 2014. Political leadership, themes, context and critiques, Oxford University Press, Oxford.

Gardner, J. 1989. On Leadership, Free Press, New York.

George, A.I. 1969. The operational code: a neglected approach to the study of political leaders and decision making, „International Studies Quarterly”, vol. 13, nr 2. DOI: https://doi.org/10.2307/3013944.

Guzzini, S., Carlsanes, W. (red.) 2011. Foreign Policy Analyses, vol. 1, Sage, London.

Haliżak, E., Pietraś, M. 2013. Wstęp, [w:] Poziomy analizy stosunków międzynarodowych, E. Haliżak, M. Pietraś (red.), Wydawnictwo Rambler, Warszawa.

Hartliński, M.T. 2012. Przywództwo polityczne, Wprowadzanie, Instytut Nauk Politycznych Uniwersytetu Warmińsko-Mazurskiego, Olsztyn.

Helms, L. Peters, G. 2012. Executive Leadership in Comparative Perspective: Politicians, Bureaucrats and Public Governance, [w:] Comparative political leadership, L. Helms (red.), Palgrave Macmillan, Houndmills, Basingstoke.

Helms, L. 2012. Introduction: The Importance of Studying Political Leadership Comparatively, [w:] Comparative political leadership, L. Helms (red.), Palgrave Macmillan, Houndmills, Basingstoke.

Hermann, M. 1998. Elementy przywództwa, [w:] Władza i spoleczeństwo, t. 2, J. Szczupaczyński (wyb. i oprac.), Wydawnictwo Naukowe Scholar, Warszawa.

Hermann, M. 1980. Explaining Foreign Policy Behavior Using the Personal Characteristic of Political Leaders, ,International Studies Quarterly”, nr 24. DOI: https://doi.org/10.2307/2600126.

Hermann, M. 1987. Assessing the Foreign Policy Role Orientations of Sub-Saharan African Leaders, [w:] Role Theory and Foreign Policy Analysis, S. G. Walker (red.), Duke University Press, Durham.

Hermann, M. 1994. President Clinton and His Advisers: An Appraisal after Seven Months, „Political Psychology", vol. 15.

Hill, Ch. 2003. The Changing Politics of Foreign Policy, Palgrave Macmillan, Houndmills, Basingstoke, Hampshire, New York.

Hudson, V. 2014. Foreign Policy analyses, classic and contemporary theory, Rowman \& Littlefield, Lanham-Boulder-New York-Toronto-Plymouth.

Holsti, O.R. 1967. Cognitive Dynamics and images of enemy, ,Journal of International Affairs”, vol. 2. 
Hudson, V. 2012. The history and evolution of foreign Policy analysis, [w:] Foreign Policy, theories, actors, cases, S. Smith, A. Hadfield, T. Dunne (red.), Oxford University Press, Oxford.

Jakubowska, U. 2001. Czym jest przywództwo polityczne, [w:] Przywództwo polityczne, T. Bodio (red.), Dom Wydawniczy i Handlowy Elipsa, Warszawa.

Jervis, R. 1976. Perception and Misperception in International Politics, Princeton University Press, Princeton.

Kaarbo, J. 1998. Leadership Styles of Prime Ministers: How Individual Differences Affect the Foreign Policymaking Process, „Leadership Quarterly”, September 9.

DOI: https://doi.org/10.1016/S1048-9843(98)90029-7.

Karwat, M. 2011. Rodzaje teorii w nauce o polityce, [w:] Czym jest teoria w politologii?, Z. Blok (red.), Wydawnictwo PWN, Warszawa.

Keohane, N. 2010. Thinking about leadership, Princeton University Press, Princeton.

Keohane, N. 2014. Western political thought, [w:] The Oxford Handbook of political leadership, R.A.W. Rhodes, P. Hart (red.), Oxford University Press, Oxford.

Kostecki, W. 2013. Poziomy analizy polityki zagranicznej, [w:] Poziomy analizy stosunków międzynarodowych, red. E. Haliżak, M. Pietraś, Wydawnictwo Rambler, Warszawa.

Lasswell, H.D. 1960. Psychopathology and Politics, Viking, New York.

Łoś-Nowak, T. 2011. Polityka zagraniczna - stałe i zmienne komponenty procesu formułowania i realizacji, [w:] Polityka zagraniczna, aktorzy, potencjaty, strategie, T. Łoś-Nowak (red.), Aspra-JR, Warszawa.

Marzęda, K. 2002. Osobowościowe uwarunkowania przywództwa politycznego, Annales Universitatis Marie Curie-Skłodowska, Sectio K, vol. 9.

Mintz, A. 2002. Integrating cognitive and rational theories of foreign policy decision making, Palgrave Macmillan, New York-Basingstoke.

Pietraś, Z.J. 1998. Decydowanie polityczne, Wydawnictwo PWN, Warszawa-Kraków.

Pietraś, Z.J. 1978. Dyplomatyczna misja specjalna jako instytucja prawa międzynarodowego, Wydawnictwo UMCS, Lublin.

Rapport, A. 2017. Cognitive approaches to Foreign Policy Analysis, Oxford Research Encyclopedia of Politics, http://politics.oxfordre.com/view/10.1093/acrefore/9780190228637.001.0001/acrefore9780190228637-e-397?print (dostęp: 12.04.2017).

Rhodes, R.A., Hart, P. 2014. Puzzles of political leadership, [w:] The Oxford Handbook of political leadership, R.A.W. Rhodes, P. Hart (red.), Oxford University Press, Oxford.

Rosenau, J. 1980. Pre-Theories and Theories of Foreign Policy, [w:] The Scientific Study of Foreign Policy, SAGE, Beverly Hills.

Rosenau, J. 1984. A Pre-Theory Revisited: World Politics in an Era of Cascading Interdependence, „International Studies Quarterly", vol. 28, nr 3. DOI: https://doi.org/10.2307/2600632.

Sajduk, B. 2009. Tradycyjne metody analizy polityki zagranicznej, [w:] Podmiotowość geopolityczna, K. Szczerski (red.), KSAP, Warszawa.

Sielski, J. 2013. Przywództwo w Unii Europejskiej, „Przegląd Politologiczny”, nr 1.

Singer, J.D. 1961. The Level-of-Analysis Problem in International Relations, „World Politics”, vol. 14, nr 1.

Smith, S. 1986. Theories of Foreign Policy. An historical overview, „Review of International Studies”, vol. 12, nr 1. DOI: https://doi.org/10.1017/S026021050011410X.

Snyder, R., Bruck, H.W, Sapin, B. 1954. Decision-Making as an Approach to the Study of International Politics (Princeton, NJ, Organizational Behavior Section), Princeton University, Foreign Policy Project, Series No. 3.

Sprout, H.M. 1957. Environmental factors in the study of international politics, „The Journal of Conflict Resolution”, vol. 1, nr 4. DOI: https://doi.org/10.1177/002200275700100401.

Stemplowski, R. 2015. Wprowadzenie do analizy polityki zagranicznej Rzeczypospolitej Polskiej, PISM, Warszawa.

Sulowski, S. 2011. Decydowanie w sprawach polityki zagranicznej państwa, [w:] Decydowanie publiczne, G. Rydlewski (red.), Dom Wydawniczy Elipsa, Warszawa. 
Tetlock, P. 2001. Psychology and international relations theory, „Annual Review of Political Science”, vol. 4.

Tetlock, P. 1999. Prospecting for evidence for prospect theory, „Contemporary Psychology”, vol. 44.

Umińska-Woroniecka, A. 2017. Siła przekonań - zastosowanie kodu operacyjnego w analizie polityki zagranicznej, „Stosunki Międzynarodowe - International Relations”, vol. 53, nr 1.

Waltz, K.W. 1959. Man, the State, and War, Theoretical Analysis, Columbia University Press, New York.

Wiatr, J. 1980. Socjologia stosunków politycznych, Wydawnictwo PWN, Warszawa.

Wendt, A. 1987. The Agent-Structure Problem in International Relations Theory, „International Organizations", vol. 41, nr 3. DOI: https://doi.org/10.1017/S002081830002751X.

Wilczyńska, E., Juja, J. 2011. Wspótczesne przywództwo charyzmatyczne a ustrój demokratyczny, „Homines Hominibus", vol. 7.

Zięba, R. 2005. Przedmowa, [w:] Wstęp do teorii polityki zagranicznej państwa, Wydawnictwo Adam Marszałek, Torun.

Żukiewicz, P. 2011. Przywództwo polityczne, teoria i praktyka, R. Zięba (red.),Wydawnictwo Difin, Warszawa.

\section{THE CONCEPT OF LEADERSHIP IN FOREIGN POLICY ANALYSIS}

Abstract: Foreign policy analysis (FPA), recognized as a sub-discipline of international relations, focused on explaining foreign policy or, alternatively, on the processes and behaviors in the framework of this policy. FPA is characterized by an actor-specific focus, based upon the argument that all that occurs between nations and across nations is grounded in human decision-makers acting singly or in groups. Explication of the process and the behavior of decision-makers may need to reach categories and tools developed within other disciplines. The main aim of the paper is to identify the emphasis of interdisciplinary research especially in the perspective adopted by the author of the individual level of analysis of foreign policy. The use of tools and categories relevant to the study of political leadership and political psychology, may allow, more than ever, verifiability of assertions in the study of foreign policy.

Keywords: foreign policy analyses, operational code theory, political leadership, cognitive approach

\section{BIOGRAM}

Anna Umińska-Woroniecka, politolog, administratywista, adiunkt w Instytucie Studiów Międzynarodowych Uniwersytetu Wrocławskiego. Autorka kilkudziesięciu artykułów, opublikowanych m.in. w: „Przeglądzie Zachodnim”, „Polskim Przeglądzie Dyplomatycznym”, „Kulturze Współczesnej”, oraz trzech monografii, w tym wydanej w 2013 roku pt. Instytuty polskie, zmiany modelowe $w$ funkcjonowaniu polskiej dyplomacji kulturalnej w latach 1998-2011. Odbyła staże badawcze na Uniwersytetach w Wielkiej Brytanii, Czechach i we Włoszech. Zainteresowania badawcze: analiza polityki zagranicznej, proces decyzyjny w polityce zagranicznej, dyplomacja, dyplomacja publiczna i dyplomacja kulturalna. Kontakt e-mail: anna. woroniecka@uni.wroc.pl. 